Vol. 8, n² | 2004

Varia

\title{
Katherine Watson, Poisoned Lives: English Poisoners and their Victims
}

London and New York, Hambledon and London, 2004, xiv + 268 p. ill., ISBN 1852853794

\section{Clive Emsley}

\section{(2) OpenEdition}

\section{Journals}

Electronic version

URL: https://journals.openedition.org/chs/500

DOI: $10.4000 /$ chs. 500

ISSN: 1663-4837

\section{Publisher}

Librairie Droz

\section{Printed version}

Date of publication: 1 November 2004

Number of pages: 184-185

ISBN: 2-600-00803-5

ISSN: 1422-0857

\section{Electronic reference}

Clive Emsley, "Katherine Watson, Poisoned Lives: English Poisoners and their Victims", Crime, Histoire \& Sociétés / Crime, History \& Societies [Online], Vol. 8, n² | 2004, Online since 28 April 2009, connection on 22 March 2022. URL: http://journals.openedition.org/chs/500 ; DOI: https://doi.org/10.4000/chs. 500

This text was automatically generated on 22 March 2022.

(C) Droz 


\section{Katherine Watson, Poisoned Lives: English Poisoners and their Victims}

London and New York, Hambledon and London, 2004, xiv + 268 p. ill., ISBN 1852853794

\section{Clive Emsley}

\section{REFERENCES}

Katherine Watson, Poisoned Lives: English Poisoners and their Victims, London and New York, Hambledon and London, 2004, xiv + 268 p. ill., ISBN 1852853794

1 In October 1848 the great moral entrepreneur Edwin Chadwick wrote an alarming letter to Sir George Grey, then home secretary:

My researches have opened to me at times, horrible revelations.

I am compelled to believe that murders escape much more frequently than is supposed. I was told by undertakers of a large practice whom I examined, that they every now and then closed the coffin lids on the corpses of adult persons whom they had strong reason to suspect from the appearance of the corpse, and from the attendant circumstances had not come fairly to their deaths; that such grounds of suspicion were more frequent as respects children.

Actuaries of insurance companies tell me of the premiums they pay in doubtful cases and sometimes in cases of which they have no doubt whatever.

2 Was Chadwick's information correct? Given, for example, the embryonic state of policing, the weakness of the coroner system and the state of forensic science at the time it is quite possible that it was. Katherine Watson's Poisoned Lives presents evidence and a sustained argument to this effect.

3 Watson's book is an examination of the criminal and in most cases murderous use of poison in England between 1750 and 1914. She has identified 540 cases of poisoning over the period drawing on court records and the printed books and pamphlets that were generated by people such as Florence Maybrick, Dr William Palmer and Dr Hawley Crippen whose behaviour caused popular sensation and scandal in Victorian and 
Edwardian England. She guides us through the variety of poisons that were readily available from chemists and others for most of the period. Arsenic, regularly used for controlling rodents and other pests, was the easiest to buy and the commonest used by those who sough to poison fellow human beings - indeed, it acquired the sobriquet 'inheritance powder'. Watson also traces the reasons that encouraged poisoners to be rid of a spouse for the sake of a lover, to be rid of an illegitimate child and so forth. Some killed for money, often the pathetic amounts available from the burial clubs to which the poor contributed in the hope of avoiding a pauper's funeral. Some killed through hatred, through jealousy or seeking retribution for some earlier offence. Murder by poisoning was not something done in the heat of the moment; it required planning and preparation. Neatly interwoven with the analysis are detailed stories from the court records sometimes tragic but more often appalling in their revelations of human callousness and greed.

4 The narrative engages usefully with some traditional myths. Poisoning, for example, was supposed to be a woman's crime - women, after all, usually had charge of the preparation of food - and if not a woman, then a doctor or chemist who had the easiest access to poison. Watson's statistics, however, show the gender division among poisoners to be almost equal and to correspond largely with the gender division of the population. Yet, since violent crime and murder was something generally committed by young men, the equal gender division of identified poisoners suggests that poison was, indeed, a woman's weapon of choice. The statistics also lead Watson to conclude that the peak of murder by poisoning was during the 1840s, a decade of serious economic hardship when the insurance industry was expanding and when, before the Arsenic Act of 1851, the sale of this substance was subject to scarcely any control. She demonstrates further that, whatever the current morbid obsession, serial killing was not simply a twentieth-century phenomenon. Several of Watson's poisoners appear to have killed on two, three or even more occasions. In 1862, for example, it was reckoned that Elizabeth Vamplew had probably poisoned three babies in a short career as a nursemaid. At the time of her conviction Vamplew was thirteen-years-old. Mary Ann Cotton, executed in Durham ten years later, may have killed five or six times as many, mainly family members and most notably stepchildren.

While the book is lively and informative, there are some disappointments. Watson mentions one or two instances of a woman being acquitted of murder by poisoning while her husband's was convicted. Was this a vestige of the old legal principle of feme covert whereby a woman could claim acquittal by arguing that she had committed an offence under the direction of her husband? Unfortunately Watson does not consider the issue. She makes much of the way that magistrates could inhibit the inquests of coroners by refusing to pay them out of the local rates, and how legislation of 1860 and 1887 gave the coroners greater autonomy and independence from such financial restrictions. Thanks to the challenging thesis of Howard Taylor, the control of the criminal justice system by financial limitation has been one of the central debates in recent years concerning the criminal statistics of the nineteenth and twentieth centuries. Unfortunately Watson does not engage with the debate nor does she make any mention of Taylor's work. These omissions detract somewhat from the overall significance of the book and might have been more profitably pursued for the reader than some of the general discussions that she provides about, for example, the prison system or the developments in policing. 


\section{AUTHORS}

\section{CLIVE EMSLEY}

The Open University, c.emsley@open.ac.uk 